logos_i_ethos_2016_(43)_numer_specjalny_2, s. 245-261

DOI: http://dx.doi.org/10.15633/lie.1972

\author{
Таня Галчева, Инна Голубович
}

\title{
Болгарский Чаадаев Янко Янева и его критики Димитр Михалчев и Петр Бицилли
}

В 1932 г. в Болгарии под заголовком Петър Чаадаев. Личност и философия была опубликована на болгарском языке книга молодого публициста Янко Янева $(1900-1945)^{1}$. Было видно, что она «стоит особняком для самого авТаня Галчева - филолог, главный редактор сайта www.savedarchives.net. Email: tanyagalcheva@gmail.com.

Инна Голубович - доктор философии, профессор Одесского национального университета И. И. Мечникова. Email: innagolub66@gmail.com. тора, отдававшего приоритет немецкой культуре» ${ }^{2}$ и, как утверждают современные знатоки истории философских идей, «превратилась в заметное для болгарской культуры событие» ${ }^{3}$.

Академической русистике имя болгарского философа, защитившего докторскую диссертацию под руководством Генриха Риккерта в Гейдельберге, мало известно. Судьба его наследия оказалась более счастливой, его труды вошли в контекст изучения истории болгарской общественной мысли, куда были возвращены спустя пять десятилетий идеологических запретов ${ }^{4}$. В двух сло-

1 Я. Янев, Петғр Чаадаев. Личност и философия, София 1932.

2 I. Elenkov, On the History of Rightist Thought in Inter-war Bulgaria: the Existential Dimension of «Crisis» in the Writings of Yanko Yanev, «Studies in East European Thought» 53 (2001) $1-2$, p. 47.

Н. И. Димитрова, Владимир Соловьев в болгарской культуре, «Соловьевские исследования» 28 (2010) 4, с. 26.

4 В этом плане следует особо отметить многолетние целенаправленные усилия болгарского философа Нины Димитровой. В качестве источника мы упоминаем здесь только последние ее публикации, притом специально обращаем внимание на вторую из них. Она 
вах о творческой биографии Янко Янева можно сказать так: выходец из маленького болгарского поселка Пещеры, поступил на историко-филологический факультет Софийского университета, а до защиты был воспитанником Лейпцигского и Фрайбургского университетов. По возвращении на родину ему не удалось устроиться преподавателем в единственном существующем тогда государственном университете. Некоторое время он был работником Университетской библиотеки, а также высокопоставленным чиновником в Министерстве народного просвещения ${ }^{5}$. С 1923 по 1934 гг. в Софии были опубликованы семь его философских книг и более чем 150 статей и рецензий в самых авторитетных болгарских журналах 6 . Однако, сколь бы ни было продуктивным его творчество, он был востребован академической средой не в Болгарии, а все в той же Германии, где жил с 1934 года. С 1936 года Янко Янев был приглашен в Берлинский университет читать лекции по болгарскому языку и истории ${ }^{7}$. В этот период к ученому пришло и публичное признание 8 . Янев погиб в 1945 г. во время одной из последних

посвящена совершенно неизученному материалу - работам Янева, напечатанным на немецком языке в последний период его жизни в Германии после 1934 г. и до его гибели в 1945 г.: Н. Димитрова, Екзистенциални измерения на «Новото време» (българската философска есеистика и публицистика в междувоенния период), София 2014; Н. Димитрова, Янко Янев: Балканско и европейско, «Български философски преглед» (2015) 5, с. 20-28.

5 Г. Шопов, Янко Янев - виден пещерски гражданин - културен дееи и интелектуалец, «Родопска искра» (2015) 3, с. 2.

6 Т. Гергова, Героичният човек Янко Янев (предговор), в: Янко Янев. Безумие и свобода. Критика и есеистика, съст. Т. Гергова, Варна 2005, http://iternet.bg/publish9/tgergova/ predgovor_yyanev.htm.

7 О том, как сложилась академическая карьера Янева в Германии, до сих пор мало известно. Некоторые пробелы можно заполнить изучением истории университета, в котором он преподавал. См. M.-L. Bott, «Deutsche Slavistik» in Berlin? Zum Slavischen Institut der Friedrich-Wilhelms-Universität 1933-1945, B: Die Berliner Universität in der NS-Zeit, Band II: Fachbereiche und Fakultäten, Berlin 2005, c. 277-298.

8 Отмар Пол утверждает: «Философ культуры, болгарин Янко Янев уже приобрел большую известность в Европе, [...] он знаком уже всему европейскому духовному миру». О. Пол, Янко Янев и неговата «Демония на столетието» ("Dämonie des Jahrhunderts. Auflage, Helingsche Verlagsanstalt, Leibzig»), «Нова Европа» (1942) 8, http://www.kanatangra.wallst.ru/ sydyrjanie.php?p=yankoyanev 1 . 
бомбежек Дрездена9. На Родине факт его смерти стал известен много лет спустя, но о философе вспомнили сразу после того как к власти в сентябре 1944 г. пришло просоветское правительство Отечественного фронта. В 1945 г. по приговору Чрезвычайной институции - Народного суда, за пропаганду фашистской идеологии Янев был заочно приговорен к пожизненному заключению ${ }^{10}$, несмотря на то, что во время заседания суда и вынесения переговора его уже не было в живых.

После этой краткой, но весьма важной для нашего изложения биографической справки, обратимся к истории создания книги Янева о русском мыслителе. 75-летний юбилей со дня смерти П. Я. Чаадаева был отмечен в Болгарии небольшой заметкой д-ра Янко Янева в литературно-художественном еженедельнике «Листопад»". Возможно, именно эта годовщина послужила поводом для того, чтобы болгарский публицист обратил внимание на одного из зачинателей русской общественной мысли. Две странички журнального текста содержат в основном известные факты из биографии «первого философского критика, первой самостоятельной личности в России» ${ }^{12}$. Интерпретация его наследия была, однако, подчеркнуто авторской:

Чаадаев выдвинул не только проблему русского самосознания, но и проблему отношения России к западно-католическому миру. [...] Чаадаев является родоначальником русского универсализма, той религиозной метафизики,

9 Многие годы в научной литературе утверждалось, что Янев умер в 1944 г. Болгарским журналистам удалось получить акт о смерти болгарского доцента философии Янко Янева, а также и полицейское дознание, в котором записано, что гибель наступила в ночь с 13 на 14 февраля 1945 г. См. А. Ганчев, За д-р Янко Янев - автентично, http://www. jankojaneff.narod.ru/Dr.Janeff.htm.

10 П. Огойски, Записки за българските страдания 1944-1989. Книга трета, София 2000, c. 11 .

11 Я. Янев, Петьр Чаадаев (По случай 75-годишнината от смъртта му), «Листопад» (1931) 7-8, с. 174-176.

12 Я. Янев, Петьр Чаадаев (По случай 75-годишнината от смғртта му), op. cit., c. 175 . 
в которой соединяются идеи западничества и славянофильства, преодолевая разрыв между западным и славянским принципами. Представление о Церкви выступает как средоточие его философии, а Церковь в его понимании - вселенская и всеобъединяющая Церковь, воплощение Христа ${ }^{13}$.

В этом тексте легко распознать основную идею первой болгарской книги о Чаадаеве. Нам, однако, удалось вскрыть некоторые незамеченные до сих пор современными болгарскими исследователями обстоятельства, говорящие о намерении Янко Янева опубликовать свое сочинение в том же самом юбилейном, 1931 году, в Германии на немецком языке. Мы рискнем предположить, что именно невозможность осуществить этот проект сказалась на судьбе болгарского Чаадаева.

Более двадцати лет тому назад была опубликована часть переписки Вячеслава Ивановича Иванова (1866-1949) с семьей Шор ${ }^{14}$. В письме В. И. Иванова к Евсею Давидовичу Шору (1891-1974) от 12 октября 1931 г. возникает неожиданная для корреспондентов сюжетная линия: по настоянию Ольги Александровны Шор (Дешарт) (1894-1978), основоположник русского символизма высказывает свое мнение о работе Янко Янева. Его откровенная реакция поражает своей резкостью суждений:

Это беспомощный лепет компилятора, который - потому ли что он не доучившийся ученик, потому ли что он не доевропеизировавшийся ориентал (6[ыть $]$ м[ожет] из болгарских мусульман) ничего не понимает и ничего не знает. В философии он еще более безграмотен, чем в немецком языке. [...] Он вообще не представляет себе культурной социальной среды, продуктом которой был Чаадаев. Все, что сказано о славянофилах, чистый вздор, нахваченный и перевранный из плохих книжек (сам он ничего не читал из источников,

13 Я. Янев, Петър Чаадаев (По случай 75-годишнината от смъртта му), ор. cit., c. 176 .

14 D. Segal, Вячеслав Иванов и семья Шор (По материалам рукописного отдела Национальной и Университетской библиотеки в Иерусалиме), «Cahiers du monde russe: Russie, Empire russe, Union soviétique, États indépendants» 35 (1994) 1-2, c. 331-352. 
кроме Чаадаева, которого пересказывает фальшиво, Гершензона, Шеллинга, чужого Чаадаеву, который вовсе не из Шеллинга вышел). [...] В результате фанатически и католически верующему Чаадаеву приписывается представление о становящемся Боге, понятие Церкви, для него основное, заменяется царством Разума. [...] Никакого Чаадаева как лица, как мыслителя, совершающего длинный и сложный диалектический процесс в помине нет. [...] Читая работу Янева, долго, очень долго недоумеваешь, почему - намеренно или нет - он упорно не упоминает о самом главном, о слоне в зверинце - о католицизме. И потому не понимает, что же служит главным основанием отрицательного суждения Чаадаева о России и ее истории ${ }^{15}$.

Публикатору цитированного документа Д. Сегалу Янев был не очень известен, ничего не упоминается и о том, была ли найдена работа, вызвавшая столь сильное раздражение. На основе позднейших, опубликованных в Германии в 1936 и 1943 гг. книг болгарского философа, был сделан, как нам кажется, весьма необоснованный вывод о том, что: “"незамечание” Яневым католицизма (вообще христианства) Чаадаева было не только далеко не случайным, но отражало суть нацистко-нативистского мировоззрения этого писателя» $^{16}$.

Немецкий текст Янева о Чаадаеве до сих пор остается неизвестным. Без ознакомления с ним нельзя провести сопоставительное исследование двух вариантов: 1931 и 1932 гг., предназначенных совершенно разным читательским кругам.

Без ответа остается и вопрос, стал ли болгарский текст результатом перевода уже написанного по-немецки "рефератика» ${ }^{17}$. Не подлежит сомнению, однако, факт, что в него были внесены дополнения: в конце предисловия цитируются источники, опубликованные на исходе 1931 г. и в 1932 г. $^{18}$.

15 D. Segal, Вячеслав Иванов и семья Шор..., ор. cit., с. 339-340.

16 D. Segal, Вячеслав Иванов и семья Шор..., ор. cit., с. 342.

17 D. Segal, Вячеслав Иванов и семья Шор..., ор. cit., с. 340.

18 Я. Янев, Петьр Чаадаев. Личност и философия, ор. cit., с. 16. 
Мы также не располагаем информацией о том, знал ли Янев о мнении В. Иванова, и если знал, как повлияла на его последующие планы жесткая и обескураживающая оценка римского профессора. Стоит, однако, учесть замечания В. И. Иванова и посмотреть на них в плоскости болгарской критической мысли. При подобном сопоставлении одни и те же утверждения могут оказаться полемичными: одновременно они представляются и безосновательными, и глубоко аргументированными.

Желание Янко Янева познакомить болгарское общество с личностью П. Я. Чаадева на первый взгляд кажется рискованным: к тому времени в Болгарии еще не только не было опубликовано ни одного издания сочинений Чаадаева, но и даже перевода хотя бы в отдельности его Философических писем, следовательно, ознакомление с его жизнью и творчеством опережало восприятие его текстов.

Между тем интерпретация молодого философа, не принадлежащего академическому кругу, не осталась незамеченной. На нее откликнулись двое из самых уважаемых профессоров Софийского университета: мэтр болгарской мысли, незыблимый авторитет Димитр Михалчев (1880-1967) и снискавший широкую известность в среде историков, филологов и культурологов, русский эмигрант, возглавляющий по контракту кафедру новой и новейшей истории Петр Михайлович Бицилли (1879-1953).

На наш взгляд, публикация, одна вслед за другой, рецензий вряд ли была случайным совпадением, несмотря на то, что они никакой полемики не преследовали. В отдельных частях мнения критиков совпадают, но в конечном счете они остаются на противоположных позициях, что побуждает к рассмотрению вопроса о том, чем обоснована эта разность. Наше внимание в отношении отзывов обоих ученых обусловлено и тем фактом, что в течение многих лет и их судьбы тоже были совершенно различными. Критическая реакция Михалчева ${ }^{19}$ часто комментируется в научной литературе как один из примеров жесткого и не до конца аргументированного 
неприятия чужой точки зрения, тогда как заметка П. М. Бицилли, если судить по библиографическим справочникам, до сих пор остается неизвестной, как исследователям наследия Янева ${ }^{20}$, так и бициллиеведам ${ }^{21}$.

Рассматриваемые отзывы «соседствовали» в самых авторитетных журналах: «Философски преглед» (под редакцией Димитра Михалчева, в котором работы Янева широко обсуждались, но не печатались, зато хорошо был принят Бицилли) и «Златорог» (где Янев сотрудничал). Нужно учитывать еще и то, что к тому времени «Философски преглед» (первое издание) завоевал себе славу уважаемой академической трибуны,тогда как «Златорог» (второе) был скорее образцом культурологической публицистики. Рецензию П. М. Бицилли ${ }^{22}$ в этом журнале можно без преувеличения назвать прецедентом, несмотря на его многочисленные публикации в болгарской периодике. Это был единственный раз, когда он выступил на страницах издания, которое в течение двух десятилетий своего существования (1920-1943) буквально оставалось законодателем моды в области литературы и искусства Болгарии. Анализируя «политику» размещения критических отзывов на книгу о Чаадаеве, трудно отделаться от впечатления, будто сами журналы оказались вовлечеными в некоторое противостояние.

Мы не будем реконструировать историю затянувшегося на много лет заочного диалога Димитра Михалчева с Янко Яневым: это уже сделано болгарским историком философии Ниной Димитровой ${ }^{23}$. По мнению исследовательницы, оппоненты радикально отличались друг от друга интеллектуальным складом и стилистикой работ, что

20 Янко Янев. Библиография, съст. Т. Гергова, в: Янко Янев. Безумие и свобода. Критика и есеистика, съст. Т. Гергова, Варна 2005, http://liternet.bg/publish9/tgergova/bibl_ yyanev.htm.

21 А. Н. Горяинов, М. А. Бирман, Библиография опубликованных работ П. М. Бицилли и литература о нем, 1912-2003. Труды П. М. Бицилли, в: П. М. Бицилли, Избранные труды по средневековой истории: Россия и Запад, ред. М. А. Юсим, Москва 2006, с. 733-778.

22 П. М. Бицилли, «Петър Чаадаев» от Янко Янев, «Златорог» (1932) 5-6, с. 282-284.

23 Н. Димитрова, Идеи върху смисъла на историята - Димитър Михалчев срещу Янко Янев, «Философски алтернативи» (2000) 3-4, с. 83-87. 
часто приводило к публичным дискуссиям. В казусе с Чаадаевым, однако, Нина Димитрова отметила, что «даже для Михалчева продемонстрированное к Я. Яневу отношение необычно резко» ${ }^{24}$. Она лишь вскользь упомянула и о рецензии П. М. Бицилли как своего рода контрапункте. Если оставить в стороне ощущение личной предубежденности Михалчева, доказательством которой мы не располагаем ${ }^{25}$, вопросы, поднятые им, не следует характеризовать как безосновательные, более того, сегодня они представляются особенно актуальными.

Несогласие Михалчева зиждется на следующих основаниях:

1. Любая напечатанная книга должна стремиться к тому, чтобы привлечь внимание интересующихся читателей «в определенное время в определенной среде». Книга Янева была написана поболгарски и резензент задается вопросом, в чем смысл ее появления, если учесть, что в Болгарии «вряд ли найдется 10 человек, интересующихся ролью и значением Чаадаева» ${ }^{26}$.

Проблема выбора лингвистического модуса является основополагающим критерием для автора любого текста, ищущего ответ на вопрос, для кого он пишет. Трудно реконструировать фигуру того читателя, которого книга Янева могла бы найти в тот момент. Несомненно, это должен был быть высоко образованный гуманитарий, глубоко просвещенный, как в области истории

24 Н. Димитрова, Идеи върху смисъла на историята - Димитър Михалчев срещу Янко Янев, ор. cit., с. 84 .

25 Предположение о том, что рецензия Михалчева была инициирована из чувства личной неприязни к Яневу имеет свои основания. Не исключено, что именно эти отношения отражены в несколько замаскированном высказывании выдающегося болгарского германиста, профессора Софийского университета Константина Галабова: «У нас ценные книги часто обходят молчанием. Кое-кто молчит, хотя и видит хорошее. С некоторыми из этих людей я знаком: книга Янева (Антихрист - Т. Г., И. Г.) им нравится, им хорошо известно, что такая книга публикуется на болгарском языке впервые, но они не желают сказать о ней и двух добрых слов. С одним из этих господ я разговаривал и он чистосердечно признался, что написал бы похвальный отзыв на книгу Янко Янева, если бы сам автор, Янко Янев, не был каким-то Бог знает каким...». К. Гълъбов, Книгата «Антихрист» от Янко Янев, «Изток. Седмичник за обществен живот и култура» 55 (1927) 5, с. 4.

26 Д. Михалчев, Янко Янев, ор. cit., с. 191. 
русской общественной мысли XIX века, так и немецкой философии: сопоставление идей Чаадаева и Шеллинга пронизывает всю книгу. Невыясненной, однако, остается проблема, почему в таком случае болгарскому читателю было представлено подробное жизнеописание русского мыслителя. Это противоречие Димитр Михалчев, вероятно, тоже заметил, потому что в рецензии повторил «в двух словах» биографию Чаадаева и сильно вознегодовал на Янева, обременившего свое изложение ненужными деталями, не имеющими никакого отношения к непосредственно поставленной задаче.

2. Второе возражение Михалчева было связано с основополагающим требованием к любому научному тексту: работе с библиографическими источниками. Сильное раздражение вызвало отношение молодого автора к предшественникам. Утверждения, что «литература о Чаадаеве к тому моменту была случайной и поверхностной» и что «историки русской философии несерьезно относятся к Чаадаеву и к нынешнему моменту» ${ }^{27}$ были точно процитированы рецензентом и побудили его перечислить произведения известных русских и зарубежных ученых, посвященные теме духовного наследия Чаадаева. Вывод критика был беспощадным: претензии автора на то, чтобы быть первопроходцем, безосновательны, он не только недооценил предыдущие работы, но с некоторыми из них даже не был знаком. Впрочем, это было отмечено более спокойным тоном и у Бицилли: «автор несправедлив к своим предшественникам» ${ }^{28}$. И эти упреки не лишены основания: некоторые утверждения Янева прямо-таки симметричны высказываниям П. Н. Милюкова ${ }^{29}$ и М. О. Гершензона ${ }^{30}$, вплоть до дословного перевода, что заставляет нас вспомнить обвинение в компиляторстве из письма В. И. Иванова.

Я. Янев, Петьр Чаадаев. Личност и философия, ор. cit., с. 15.

П. М. Бицилли, «Петър Чаадаев», ор. cit., с. 283.

П. Милюков, Главные течения русской исторической мысли, т. 1, Москва 1897.

М. Гершензон, П. Я. Чаадаев. Жизнь и мышление, Санкт-Петербург 1908. 
3. Критике со стороны Михалчева был подвергнут и «восторг болгарского биографа по поводу философско-исторических идей Чаадаева ${ }^{31}$. Университетский профессор строго напомнил о наследии Платона, Полибия, св. Августина, Гердера и Джанбатиста Вико, после чего заключил, что теория Чаадаева развита красиво и темпераментно, но что она нисколько не оригинальна.

Согласиться с Михалчевым в этом пункте нельзя. Янев фокусирует внимание на самобытности русского мыслителя на фоне его времени и среды. В книге неоднократно повторяется формула: «первый в России». Биограф не стремится творить образ героя в иконописных тонах, его цель - воссоздать те обстоятельства, которые обусловили духовное развитие Чаадаева. Концепция русского мыслителя ценна для болгарского философа тем, что она мотивирована поиском национальной идентичности и озабоченностью будущим родной страны. Действительно, Янев часто подчеркивает уникальность фигуры Чаадаева, но и не забывает отметить, что критика Чаадаева распадается на отдельные мысли, которые встречаются в разных вариантах и не объединяются в цельную систему.

4. Наверное самые резкие высказывания Михалчева в адрес Янева вызваны стилем автора. Из них, без переувеличения, можно было бы составить словарь выпадов: «литературная и словесная пена, в которой любит купаться г. Янев»; «сравнения тоже должны быть в меру»; «запутанная фразеология» ${ }^{32}$ и т.д. Заканчивается рецензия университетского профессора следующим обобщением: «Новая книга г. Янева является доказательством того, что он обладает некоторым даром, но это не дар философского писателя» ${ }^{33}$.

В такой позиции Михалчева проглядывает платоновское заключение о раздоре между поэзией и философией. До того как стать философом, Янев опубликовал три книги стихов и это не прошло бесследно. Публицистический пафос, динамика речи, ритм, богатство 
словарного запаса, а также краткие высказывания и лаконичные предложения, без синтактических вставок и больших фраз, господствуют в его текстах и, вне всякого сомнения, привлекают к ним самого разнообразного, порой непрофессионального читателя. С этой точки зрения следует признать, что Яневу принадлежит особое место в болгарской философской традиции: как мало кто другой, он умел доступно писать о том, что обычно обсуждается в университетских аудиториях.

Нам не известны материалы, свидетельствующие о личных отношениях между Яневым и Михалчевым. Сохранились, однако, следы, по которым можно судить о том, что молодой болгарский философ знал и высоко ценил работы П. М. Бицилли. В 1928 г. Янев опубликовал рецензию на книгу профессора, написанную на болгарском языке и предназначенную для болгарских студентов ${ }^{34}$. Можно в связи с этим предположить, что отзыв о сочинении Янева был неким ответным жестом: вероятно, издание о Чаадаеве было вручено им в качестве подарка, о чем свидетельствуют надпись и датировка: «Многоуважаемому г[осподину] проф. П. Бицилли. 2.III.32» ${ }^{35}$.

Нельзя утверждать наверняка, что появление рецензии П. М. Бицилли на книгу Я. Янева было вызвано единственно желанием смягчить эффект резкости выступления Д. Михалчева, хотя такое намерение проскальзывает сквозь сдержанность тона. Критик нашел работу болгарского философа «очень ценной» ${ }^{36}$ и этим исчерпал все достоинства издания. Он не стал объяснять или защищать свою позицию и не подверг анализу авторские достижения: они для него субъективно обоснованы и очевидны.

Для Бицилли необходимость в появлении новых материалов о Чаадаеве была несомненной. Историк специально отметил этот

34 Я. Янев, Един увод в новата история. П. Бицилли. Увод в изучаването на новата и най-новата история. София 1927, стр. 341, «Българска мисъл» (1928) 2, с. 156-158.

35 Л. В. Герашко, В. Б. Кудрявцев, Фонд профессора П. М. Бицилли в Рукописном отделе Пушкинского Дома, в: Ежегодник Рукописного отдела Пушкинского Дома на 2005-2006 годы, ред. Т. С. Царькова, Санкт-Петербург 2009, с. 137.

36 П. М. Бицилли, «Петьр Чаадаев», ор. cit., с. 283. 
факт в одной из первых, опубликованных на болгарском языке статей $^{37}$, написанной только год спустя после его переезда из Скопье в Софию. В центре его внимания в ней следующая и основная мысль: по своему историческому развитию народы принадлежат двум типам: «органическому» и «катастрофическому». Развитие России нужно отнести ко второму типу, для которого характерны: «необходимость узнать самого себя, найти “свой собственный путь” и “свое собственное призвание”, так или иначе рационализировать собственную историю, обнаружить в ней единую, общую, направляющую ее “идею”» ${ }^{38}$. С этой точки зрения, продолжает ученый, особенно интересна фигура Чаадаева.

Нигде в своей книге Янев не ссылается на упомянутый текст Бицилли. Мы бы рискнули предположить, однако, что он был ему известен: слово за словом философ повторил наблюдение историка о близости Чаадаева с Достоевским, притом в качестве примера (точно также) указал на речь Достоевского о Пушкине ${ }^{39}$. Янев по-своему продолжил и еще одну подброшенную Бицилли идею: о влиянии Новалиса и Шлегеля на теоретические и мировоззренческие конструкции Чаадаева, о духовном родстве русского мессианства и универсализма немецких мыслителей эпохи раннего романтизма. Так была обозначена одна из тем заочной дискуссии с В. И. Ивановым.

Вероятно эти совпадения не ускользнули от внимания профессора: в своем отзыве он намекнул автору на это и одновременно заочно вступил в полемику с Михалчевым. П. М. Бицилли подчеркнул,

37 П. Бицили, Двата пътя на историческото развитие на народите, «Българска мисъл» (1926) 4-5, с. 442-457. Статья являлась продолжением доклада, сделанного П. М. Бицилли во время III съезда русских ученых в Праге в 1924 г. Еще на эту тему см. Т. Н. Галчева, И. В. Голубович, «Понемногу приспособляюсь к “независящим обстоятельствам”». П. М. Бицилли и семья Флоровских в первые годы эмиграции, София 2015, c. $252-253$.

38 П. Бицили, Двата пътя на историческото развитие на народите, в: П. Бицили, Малки творби, София 2003, с. 43-44.

39 П. Бицили, Двата пбтя на историческото развитие на народите, op. cit., с. 45; Я. Янев, Петьр Чаадаев. Личност и философия, ор. cit., с. 114. 
что хотя элементы религиозно-философской концепции Чаадаева восходят к Шеллингу, Жозефу де Местру и к другим романтикам, русского мыслителя нельзя считать «вульгаризатором» чужых идей. Рецензент посчитал работу Янева удачной, поскольку в ней была обоснована оригинальность Чаадаева, состоящая в том, что прошлое и современность России рассматривались «с точки зрения вечности» ${ }^{40}$.

Наблюдается и резкое расхождение между мнениями П. М. Бицилли и В.И. Иванова о результатах работы Янева относительно индивидуализации образа П. Я. Чаадаева. Пользуясь стилистической фигурой отстраненности, историк не стал навязывать читателю свою точку зрения, но не преминул четко высказать свое согласие: «Насколько я могу судить, автор дал психологически тонкую и правильную характеристику Чаадаева...» ${ }^{41}$ (сразу вспоминается уже приведенная цитата из письма В. И. Иванова: «Никакого Чаадаева как лица, как мыслителя [...] в помине нет...»).

К недостаткам, однако, П. М. Бицилли, согласно его собственному признанию, отнесся с «осторожностью», а свои возражения он высказал дипломатичным, доходящим до снисходительности тоном («я не сомневаюсь в том, что автору известно, что христианство проникло в Россию лишь в десятом веке и что Патриарх Никон жил в семнадиатом веке» ${ }^{42}$ ). Смягчить и уравновесить резкую контрастность между этим мнением и заключением В. И. Иванова («все равно не исчерпать все ошибки, несуразности, наивности, невежественности этого элабората» ${ }^{43}$ ) очень, очень трудно, даже принимая во внимание факт, что немецкий текст Янева нам не известен... А мнение Иванова высказано в частной форме - в письме, с характерной для личной корреспонденции несдержанностью и излишней преувеличенностью в данном случае тяготения Чаадаева «к католицизму».

40 П. М. Бицилли, «Петьр Чаадаев», ор. cit., с. 283.

41 П. М. Бицилли, «Петгр Чаадаев», ор. cit., с. 282.

42 П. М. Бицилли, «Петгр Чаадаев», ор. сit., с. 283.

43 D. Segal, Вячеслав Иванов, ор. cit., с. 340. 
Утверждающий пафос рецензии П. М. Бицилли заставляет задуматься и побуждает к обсуждению вопроса о ценности выстроенной Янко Яневым схемы. Легко найти ее в рамках библиографической выписки: вопреки своим недостаткам, книга молодого философа явилась первым болгарским источником для ознакомлении с личностью и мировоззрением П. Я. Чаадаева. При этом она отнюдь не была популяризаторским изложением, а требовала от читателя глубокой погруженности в историю русской мысли. Самоуверенность автора, с одной стороны, вызывала возражение своим неуважением и даже невнимательным отношением к источникам (в чем, между прочим, упрекали самого Чаадаева Милюков и тот же Янев). С другой стороны, однако, позиция болгарского интерпретатора русского наследия задавала иные правила для ведения диалога между «чужым» и «своим»: пересмотру и переоценке подлежат все уже высказанные ранее мнения, даже те, которые были вроде бы усвоены. Янев, например, даже не стал полемизировать с Гершензоном о дате рождения Чаадаева, выписке из родовой книги он противопоставил собственный способ, как следует синхронизировать разные исторические источники; творчески усваивая основные элементы изложения Гершензона, он не постеснялся назвать его работу «особой». Отметим также, что оптика видения чужого мира, чужой политики, позволяет Яневу сделать некоторые профетические заключения: например, о роли ложного обвинения в сумасшествии как инструмента расправы над неугодными («это средство - единственное по своей ироническо-христианской снисходительности во всей истории» ${ }^{44}$ ).

Свобода воззрений и отсутствие комплексов позволили молодому философу воссоздать цельный и гармоничный образ П. Чаадаева и в этом смысле, нам кажется, следует искать объяснение долговечной ценности высказанных им суждений.

Согласно концепции Янева, биография русского мыслителя, вопреки резким поворотам и переменам, не распадается на куски, подчерквается примиряющее начало между всеми внутренними 
противоречиями: «Личность и учение этого религиозного созерцателя идут нераздельно» ${ }^{45}$. Прослеживая судьбу Чаадаева, воскресив его идейные шатания, Янев приходит к заключению о том, что его герой отличался «внутренней согласованностью идей философии с позицией собственной жизни, руководствуясь для самооправдания мотивами высшего религиозного и метафизического сознания» ${ }^{46}$.

Автор не боится использовать категории антиномического мышления: полемика со славянофилами рассматривается им как существенная часть мировоззренческого опыта Чаадаева. Вследствие этого мыслитель на протяжении своего развития из убежденного западника «переродился в не менее убежденного славянофила, хотя и не в том узком смысле, как его предыдущие неприятели» ${ }^{47}$. Примирением снято и противоречие между католичеством и православием: будучи под влиянием латинских авторов, в глазах Янева его герой остался глубоко верным истинному христианскому идеалу, проповедуемому русской Церковью.

В предисловии болгарской книги приводится цитата из Апологии сумасшедшего, в которой провозглашается культ истины в познании Отечества. В ней молодой философ, творчески осваивая немецкую и русскую традиции, помимо других вопросов, ответил и на следующий: как существовать «между» (between) любовью к родине и любовью к истине? Пафос его утверждения зиждется на другом союзе - «в» (in): - в познании прошлого и в примирении религиозных начал.

\section{Библиография}

Бицили П., Малки творби, София 2003.

Бицилли П. М., «Петър Чаадаев» от Янко Янев, «Златорог» (1932) 5-6, с. 282-284.

45 Я. Янев, Петгр Чаадаев. Личност и философия, ор. cit., с. 33.

46 Я. Янев, Петгр Чаадаев. Личност и философия, ор. cit., с. 34.

47 Я. Янев, Петьр Чаадаев. Личност и философия, ор. cit., с. 106. 
Бицилли П. М., Избранные труды по средневековой истории: Россия и Запад, ред. М. А. Юсим, Москва 2006.

Галчева Т. Н., Голубович И. В., «Понемногу приспособляюсь к “независящим обстоятельствам”». П. М. Бииилли и семья Флоровских в первые годы эмиграции, София 2015.

Ганчев А., За д-р Янко Янев - автентично, http://www.jankojaneff.narod.ru/Dr. Janeff.htm.

Герашко Л. В., Кудрявцев В. Б., Фонд профессора П. М. Бицилли в Рукописном отделе Пушкинского Дома, в: Ежегодник Рукописного отдела Пушкинского Дома на 2005-2006 годы, ред. Т. С. Царькова, Санкт-Петербург 2009, с. 57-222.

Гершензон М., П. Я. Чаадаев. Жизнь и мышление, Санкт-Петербург 1908.

Гълъбов К., Книгата «Антихрист» от Янко Янев, «Изток. Седмичник за обществен живот и култура» 55 (1927) 5, с. 4.

Димитрова Н., Идеи върху смисъла на историята - Димитьр Михалчев срешу Янко Янев, «Философски алтернативи» (2000) 3-4, с. 83-87.

Димитрова Н. И., Владимир Соловьев в болгарской культуре, «Соловьевские исследования» 28 (2010) 4, с. 22-27.

Димитрова Н., Екзистенциални измерения на «Новото време» (българската философска есеистика и публицистика в междувоенния период), София 2014.

Димитрова Н., Янко Янев: Балканско и европейско, «Български философски преглед» (2015) 5, с. 20-28.

Огойски П., Записки за българските страдания 1944-1989. Книга трета, София 2000.

Милюков П., Главные течения русской исторической мысли, т. 1, Москва 1897.

Михалчев Д., Янко Янев. П. Чаадаев, «Философски преглед» (1932) 2, с. 190-195.

Пол О., Янко Янев и неговата «Демония на столетието» («Dämonie des Jahrhunderts. Auflage,Helingsche Verlagsanstalt, Leibzig»), «Нова Европа» (1942) 8, http://www. kanatangra.wallst.ru/sydyrjanie.php?p=yankoyanev1.

Шопов Г., Янко Янев - виден пещерски гражданин - културен дееи, и интелектуалеи, «Родопска искра» (2015) 3, с. 2.

Янев Я., Един увод в новата история. П. Бицилли. Увод в изучаването на новата и най-новата история. Собия 1927, стр. 341, «Българска мисъл» (1928) 2, c. $156-158$. 
Янев Я., Петър Чаадаев (По случай 75-годишнината от смъртта му), «Листопад» (1931) 7-8, с. 174-176.

Янев Я., Петьр Чаадаев. Личност и философия, София 1932.

Янко Янев. Безумие и свобода. Критика и есеистика, съст. Т. Гергова, Варна 2005, http://liternet.bg/publish10/yanko_yanev/svoboda.

Bott M.-L., «Deutsche Slavistik» in Berlin? Zum Slavischen Institut der Friedrich-Wilhelms-Universität 1933-1945, in: Die Berliner Universität in der NS-Zeit, Band II: Fachbereiche und Fakultäten, Berlin 2005, c. 277-298.

Elenkov I., On the History of Rightist Thought in Inter-war Bulgaria: the Existential Dimension of «Crisis» in the Writings of Yanko Yanev, «Studies in East European Thought» 53 (2001) 1-2, с. 47-59.

Segal D., Вячеслав Иванов и семья Шор (По материалам рукописного отдела Национальной и Университетской библиотеки в Иерусалиме), «Cahiers du monde russe: Russie, Empire russe, Union soviétique, États indépendants» 35 (1994) 1-2, c. 331-352. 